\title{
Faktor-Faktor yang Mempengaruhi Ekspor Jahe Indonesia
}

\author{
Ami Rismiyati ${ }^{1 *}$, Rahma Nurjanah ${ }^{2}$, Candra Mustika $^{3}$ \\ ${ }^{1,2,3}$ Prodi Ekonomi Pembangunan, Fakultas Ekonomi dan Bisnis, Universitas Jambi

\begin{tabular}{|l|l|l|l|} 
Diterima: $18-11-2021$ & Direvisi: $25-12-2021$ & Disetujui: 27-12-2021 & Dipublikasi: 31-12-2021 \\
\hline
\end{tabular}

\begin{abstract}
This study aims to analyze the effect of the exchange rate, price, production, and inflation variables on Indonesian ginger exports. The data used is secondary data in the form of time series data with 28 years (1990-2017) obtained from government agencies such as the Central Statistics Agency, the Ministry of Trade, and the Directorate General of Plantations. Data were analyzed using multiple linear regression analysis. The results showed that the exchange rate had a negative effect, and production positively affected Indonesia's ginger exports. On the other hand, the price and inflation did not significantly affect.
\end{abstract}

Keywords: export, ginger, exchange rate, price, production, inflation

\begin{abstract}
Abstrak
Penelitian ini bertujuan untuk menganalisis pengaruh dari variabel kurs, harga, produksi, dan inflasi terhadap ekspor jahe Indonesia. Data yang digunakan adalah data sekunder berupa data time series dengan kurun waktu 28 tahun (1990-2017) yang diperoleh dari instansi pemerintahan seperti Badan Pusat Statistik, Kementrian Perdagangan, dan Direktorat Jendral Perkebunan. Data dianalisis dengan alat analisis regresi linear berganda. Hasil penelitian menunjukkan bahwa kurs berpengaruh negatif dan produksi berpengaruh positif terhadap ekspor jahe Indonesia. Sebaliknya, harga dan inflasi tidak berpengaruh signifikan.
\end{abstract}

Kata kunci: ekspor, jahe, kurs, harga, produksi, inflasi

\section{Pendahuluan}

Kaum merkantilis mengatakan bahwa setiap negara yang ingin maju harus melakukan perdagangan luar negeri atau perdagangan internasional, dalam era globalisasi menunjukkan bahwa tidak satu negara pun di dunia dapat hidup dan maju dengan sendirinya. Bentuk paling umum dalam kegiatan perdagangan internasional adalah ekspor dan impor, baik itu untuk dapat memenuhi barang dan jasa dalam negeri, maupun memperluas pemasaran produk yag melimpah disuatu negara dan tidak dimiliki oleh negara lain dengan tujuan keuntungan dan meningkatkan pendapatan negara.

Perdagangan internasional adalah perdagangan yang dilakukan dua negara berbeda atau lebih yang bertujuan baik karena keuntungan, politik, hutang, ataupun ketergantungan terhadap suatu negara. kegiatan dalam perdagangan internasional yaitu ekspor dan impor. Ekspor adalah kegiatan memasukkan barang dalam negeri ke negara lain dengan melakukan berbagai prosedur dan sistem pembayaran yang telah disetujui kedua pihak eksportir dan importir yang tidak lepas dari campur tangan bea cukai. Ekspor merupakan bagian penting dalam perdagangan internasional dalam ekspor impor dibagi menjadi dua komponen yaitu migas dan nonmigas.

\footnotetext{
* Penulis korespondensi

Email: amirismiyati@gmail.com
} 
Barang migas adalah barang yang dihasilkan dari pertambangan berupa minyak bumi dan gas, sedang Barang Nonmigas adalah barang bukan berupa minyak bumi dan gas atau barang yang dihasilkan dari usaha pengolahan berupa hasil perkebunan, perternakan, pertanian, perikanan, dan hasil pertambangan yang bukan minyak dan gas. Ekspor migas adalah primadona ekspor Indonesia selama pertengahan tahun 1980-an kebawah, adapun kelompok komoditi ekspor migas yang peranannya sangat menonjol saat itu adalah minyak bumi dan gas, kemudian terus mengalami penurunan sepanjang waktu berjalan.

Ekspor non migas adalah kegiatan ekspor yang peranannya semakin besar setelah pertengahan tahun 1980-an. secara garis besar ekspor non migas dapat dikelompokan menjadi tiga sektor yaitu ekspor hasil pertanian, ekspor hasil industri pengolahan, serta ekspor hasil pertambangan dan lainnya. Didalam sektor pertanian terdapat berbagai macam karakteristik komoditas yang dikelompokkan ke dalam 5 sub sektor yaitu, sub sektor tanaman pangan, sub sektor perkebunan, sub sektor kehutanan, sub sektor perikanan, dan sub sektor perternakan.

Tanaman obat atau biofarmaka adalah bagian dari sub sektor pertanian, merupakan salah satu ekspor 10 komoditi potensial pada tahun 2017 diantaranya yaitu produk kulit, peralatan medis, tanaman obat, makanan olahan, minyak atsiri, produk perikanan, kerajinan, perhiasan, rempah-rempah, dan peralatan kantor. Tanaman obat terdiri dari berbagai jenis tanaman, salah satu tanaman yang diekspor adalah jahe. Berikut adalah perkembangan variabel-variabel selama lima tahun terakhir.

Tabel 1. Ekspor Jahe, Kurs, Harga, Produksi Dan Inflasi Indonesia, 2013 - 2017

\begin{tabular}{cccccc}
\hline Variabel & $\mathbf{2 0 1 3}$ & $\mathbf{2 0 1 4}$ & $\mathbf{2 0 1 5}$ & $\mathbf{2 0 1 6}$ & $\mathbf{2 0 1 7}$ \\
\hline Ekspor Jahe & 27,128 & 68,427 & 27,762 & 33,324 & 24,959 \\
Kurs & 10,563 & 11,884 & 13,458 & 13,330 & 13,398 \\
Harga & 0.85 & 0.86 & 0.96 & 0.9 & 1.27 \\
Produksi & 155,256 & 226,115 & 313,064 & 340,341 & 216,587 \\
Inflasi & 8.28 & 8.36 & 3.35 & 3.02 & 3.61 \\
\hline
\end{tabular}

Sumber : Badan pusat statistik, 2018 (data diolah)

Indonesia merupakan salah satu negara supplier tanaman obat di dunia bersama Republik Rakyat Tiongkok (RRT) dan India. Indonesia dikenal sebagai negara mega biodiversity terbesar kedua setelah Brazil. Salah satu kekayaan alam yang dimiliki adalah tingginya keanekaragaman hayati termasuk tanaman obat-obatan sebagai bahan baku jamu (PT. Sido Muncul, dalam Salim \& Munadi, 2017).

Jahe adalah salah satu komoditas tanaman pangan yang diperjual-belikan dipasar internasional. Jahe dibutuhkan sebagai bahan rempah-rempah dan obat-abatan tradisional maka jahe. Dewasa ini jahe telah menjadi salah satu komoditas ekspor yang permintaannya cukup tinggi. Kendala yang ditemui oleh para eksportir adalah pasokan jahe dari sentra-sentra produksi tidak mencukupi. Adapun negara-negara tujuan ekspor adalah Amerika Serikat, Belanda, Uni Emirat Arab, Pakistan, Jepang, Hongkong (Pribadi, 2009).

Sebagai negara agraris yang terkenal dengan kesuburannya Indonesia seharusnya mampu menjadi negara pengekspor tanaman obat khususnya jahe diatas RRT dan India karena Indonesia memiliki struktur tanah, letak geografis, dan cuaca yang cocok untuk ditanami jahe. namun ternyata Indonesia tidak mampu merebut pangsa pasar yang diharapkan. Berdasarkan uraian tersebut maka penulis tertarik melakukan penelitian mengenai faktor-faktor yang mempengaruhi ekspor jahe Indonesia.

\section{Metode}

Data yang digunakan adalah data sekunder berupa data time series periode 1990-2017. Data bersumber dari Badan Pusat Statistik, Bank Indonesia, Kementrian Perdagangan, dan Direktorat Jenderal Perkebunan, Direktorat Jenderal Pertanian. Data yang digunakan diantaranya adalah volume ekspor jahe Indonesia, kurs rupiah terhadap dollar Amerika 
Serikat, harga komoditi jahe di dunia, Produksi jahe di Indoneisa, dan Inflasi. Metode analisis data yang digunakan adalah analisis deskriptif dan kuantitatif dan di uji asumsi klasik dengan uji multikolinearitas, uji autokorelasi, uji heterokedastisitas, uji normalistas, dan uji linearitas. Untuk menganalisis pengaruh kurs, harga, produksi, dan inflasi terhadap ekspor jahe Indonesia maka digunakan formula sebagai berikut :

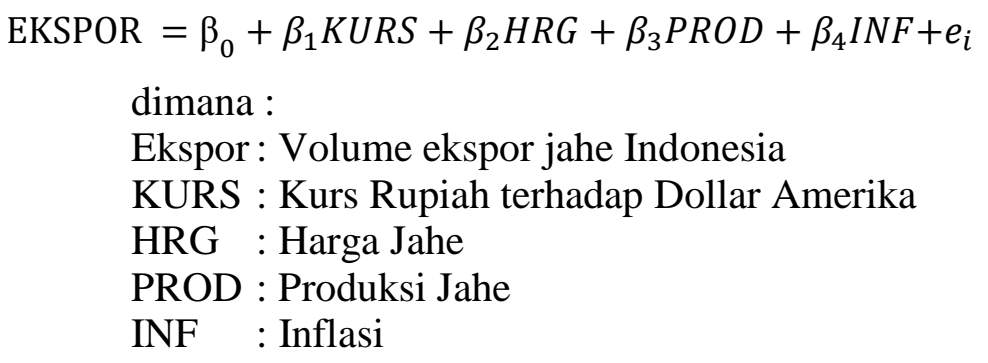

\section{Hasil dan Pembahasan}

\section{Perkembangan Kurs}

Kondisi kurs rupiah terhadap dollar selama 1990-2017 terus berfluktuasi atau naik dan turun. Kurs rupiah mengalami depresiasi terbesar pada tahun 1997 sebesar 95.13 persen disebabkan karena krisis moneter yang dialami Indonesia. sedangkan pada tahun 2010 mengalami apresiasi sebesar - 12.34 persen disebabkan mulai pulihnya perekonomian negaranegara yang terkena imbas krisis global, upaya pemulihan ini dimulai pada tahun 2009 hasilnya kurs terapresia sebesar 5.98 persen. rata-rata perkembangan kurs terhadap dollar sebesar 9.43 persen pertahun periode 1990-2017.

Tabel 2. Perkembangan Kurs 2004-2017

\begin{tabular}{|c|c|c|}
\hline Tahun & Kurs & Perkembangan \\
\hline 1990 & 1901 & - \\
\hline 1991 & 1992 & 4.79 \\
\hline 1992 & 2308 & 15.86 \\
\hline 1993 & 2110 & -8.58 \\
\hline 1994 & 2200 & 4.27 \\
\hline 1995 & 2308 & 4.91 \\
\hline 1996 & 2383 & 3.25 \\
\hline 1997 & 4650 & 95.13 \\
\hline 1998 & 8025 & 72.58 \\
\hline 1999 & 7100 & -11.53 \\
\hline 2000 & 9595 & 35.14 \\
\hline 2001 & 10266 & 6.99 \\
\hline 2002 & 9261 & -9.79 \\
\hline 2003 & 8571 & -7.98 \\
\hline 2004 & 9030 & 5.36 \\
\hline 2005 & 9751 & 7.98 \\
\hline 2006 & 9141 & -6.26 \\
\hline 2007 & 9142 & 0.01 \\
\hline 2008 & 9772 & 6.89 \\
\hline 2009 & 10356 & 5.98 \\
\hline 2010 & 9078 & -12.34 \\
\hline 2011 & 8773 & -3.36 \\
\hline 2012 & 9419 & 7.36 \\
\hline 2013 & 10563 & 12.15 \\
\hline 2014 & 11884 & 12.51 \\
\hline 2015 & 13458 & 13.24 \\
\hline 2016 & 13330 & -0.95 \\
\hline 2017 & 13398 & $0.51 \mathrm{~s}$ \\
\hline Rata-rata & & 9.43 \\
\hline
\end{tabular}

Sumber: SEKI BI, diolah Kementerian Perdagangan (data diolah, 2018) 
Tahun 1990 kurs rupiah terhadap dollar sebesar Rp. 1.901, tahun 1991 menjadi Rp. 1.992 depresiasi 4.79 persen. tahun 1992 menjadi Rp. 2.308 depresiasi 15.86 persen. tahun 1993 rupiah menguat menjadi Rp. 2.110 kemudian tahun 1994 rupiah kembali mengalami depresiasi menjadi Rp. 2.200. Rupiah terus mengalami depresiasi tahun 1995 hingga 1998 masing-masing Rp. 2.308 Rp. 2.383, puncak krisis moneter tahun 1997-1998 berimbas pada nilai rupiah yang melemah, ditahun 1997 rupiah mengalami depresiasi yang sangat besar yaitu 95.13 persen dengan kurs Rp.4.650, kondisi tersebut berlanjut ditahun 1998 kurs sebesar Rp. 8025 terdepresiasi sebesar 72.58 persen, tahun 1999 rupiah menguat menjadi Rp. 7.100, namun kembali depresi 35.14 persen tahun 2000 kurs sebesar Rp. 9.595. tahun 2001 juga deperiasi 6.99 persen dengan kurs sebesar Rp. 10.266. tahun 2002 rupiah mengalami apresiasi sebesar 9.79 persen dengan kurs sebesar Rp. 9.261.

\section{Perkembangan Harga Jahe}

Harga komoditi jahe di dunia selama tahun 1990-2017 berfluktuasi. Harga jahe memiliki rata-rata perkembangan sebesar -0.64 persen pertahun ini mengartikan bahwa selama 1990 sampai 2017 harga jahe sebesra 64 persen mengalami penurunan. Jika diperhatikan harga jahe didunia umumnya mengalami penurunan sehingga harga jahe di dunia murah. Perkembangan harga tertinggi terjadi pada tahun 2003 sebesar 39.80 persen, disebabkan karena nilai kurs rupiah terhadap US\$ terapresiasi selain itu permintaan dipasar dunia meningkat. Sedangkan perkembangan harga terendah terjadi pada tahun 2013 sebesar 126.74 persen disebabkan karena nilai kurs rupiah terhadap US\$ menurun atau mengalami depresiasi selain itu juga inflasi meningkat dari tahun sebelumnya tetapi inflasinya masih dalam level ringan.

Tabel 3. Perkembangan Harga Jahe 1990-2017

\begin{tabular}{ccc}
\hline Tahun & Harga Jahe & Perkembangan \\
\hline 1990 & 0.32 & - \\
1991 & 0.46 & 30.43 \\
1992 & 0.42 & -9.52 \\
1993 & 0.38 & -10.53 \\
1994 & 0.35 & -8.57 \\
1995 & 0.38 & 7.89 \\
1996 & 0.47 & 19.15 \\
1997 & 0.55 & 14.55 \\
1998 & 0.30 & -83.33 \\
1999 & 0.35 & 14.29 \\
2000 & 0.51 & 31.37 \\
2001 & 0.52 & 1.92 \\
2002 & 0.59 & 11.86 \\
2003 & 0.98 & 39.80 \\
2004 & 0.57 & -71.93 \\
2005 & 0.67 & 14.93 \\
2006 & 0.88 & 23.86 \\
2007 & 0.83 & -6.02 \\
2008 & 0.64 & -29.69 \\
2009 & 0.90 & 28.89 \\
2010 & 1.40 & 35.71 \\
2011 & 2.29 & 38.86 \\
2012 & 1.95 & -17.44 \\
2013 & 0.86 & -126.74 \\
2014 & 0.86 & 0.00 \\
2015 & 0.96 & 10.42 \\
2016 & 0.90 & -6.67 \\
2017 & 1.27 & 29.13 \\
\hline Rata-rata & & -0.64 \\
\hline
\end{tabular}

Sumber: Badan Pusat Statistik, 2018 (Data diolah) 


\section{Perkembangan Produksi}

Perkembangan produksi jahe Indonesia periode 1990-2017 berfluktuasi namun umumnya mengalami peningkatan. Produksi jahe Indonesia memiliki rata-rata perkembangan sebesar 10.17 persen pertahun mengartikan bahwa produksi selama 1990 sampai 2017 mengalami peningkatan sebesar 10 pesen. Perkembangan produksi jahe tertinggi terjadi pada tahun 2006 yakni sebesar 188.05 persen, perkembangan yang tinggi tersebut disebabkan dengan bertambahnya luas lahan budidaya tanaman jahe dimana luas lahan bertambah sekitar dua puluh ribu Ha sehingga menghasilkan produksi jahe 3x lipat dari tahun sebelumnya. Sedangkan perkembangan produksi jahe terendah terjadi pada tahun 2005 sebesar -41.32 persen, disebabkan oleh berkurangnya lahan budidaya jahe.

Tabel 4. Perkembangan Produksi Jahe 1990-2017

\begin{tabular}{ccc}
\hline Tahun & Produksi jahe & Perkembangan \\
\hline 1990 & 79,891 & - \\
1991 & 88,566 & 10.86 \\
1992 & 94,505 & 6.71 \\
1993 & 88,573 & -6.28 \\
1994 & 75,991 & -14.21 \\
1995 & 82,631 & 8.74 \\
1996 & 80,471 & -2.61 \\
1997 & 77,572 & -3.60 \\
1998 & 70,000 & -9.76 \\
1999 & 148,500 & 112.14 \\
2000 & 130,300 & -12.26 \\
2001 & 105,300 & -19.19 \\
2002 & 110,700 & 5.13 \\
2003 & 125,385 & 13.27 \\
2004 & 104,789 & -16.43 \\
2005 & 61,495 & -41.32 \\
2006 & 177,138 & 188.05 \\
2007 & 178,502 & 0.77 \\
2008 & 154,964 & -13.19 \\
2009 & 122,181 & -21.16 \\
2010 & 107,735 & -11.82 \\
2011 & 94,743 & -12.06 \\
2012 & 114,537 & 20.89 \\
2013 & 155,286 & 35.58 \\
2014 & 226,115 & 45.61 \\
2015 & 313,064 & 38.45 \\
2016 & 340,341 & 8.71 \\
2017 & 216,587 & -36.36 \\
\hline Rata-rata & & 10.17 \\
\hline
\end{tabular}

Sumber: Badan Pusat Statistik, 2018 (Data diolah)

\section{Perkembangan Inflasi}

Rata-rata perkembangan inflasi Indonesia yang terjadi selama 1990-2017 adalah 44.67 persen pertahun. Inflasi yang terus berubah-ubah, dimana inflasi tertinggi terjadi tahun 1998 sebesar 77.63 persen merupakan akibat dari krisis moneter yang melanda kawasan asia termasuk Indonesia krisis ini terjadi dari tahun 1997, selain itu polemik politik yang memanas juga menjadi sebab Indonesia mengalami hyper inflation. Inflasi terendah tahun 1999 sebesar 2.01 persen, dengan perkembangan inflasi sebesar -97.41 persen. Inflasi termasuk salah satu variabel yang mempengaruhi ekspor suatu negara. Adapun perkembangan inflasi dapat dilihat pada Tabel 5. 
Tabel 5. Perkembangan Inflasi 1990-2017

\begin{tabular}{ccc}
\hline Tahun & Inflasi & Perkembangan \\
\hline 1990 & 9.53 & - \\
1991 & 9.52 & -0.10 \\
1992 & 4.94 & -48.11 \\
1993 & 9.77 & 97.77 \\
1994 & 9.24 & -5.42 \\
1995 & 8.64 & -6.49 \\
1996 & 6.47 & -25.12 \\
1997 & 11.05 & 70.79 \\
1998 & 77.63 & 602.53 \\
1999 & 2.01 & -97.41 \\
2000 & 9.35 & 365.17 \\
2001 & 12.55 & 34.22 \\
2002 & 10.03 & -20.08 \\
2003 & 5.06 & -49.55 \\
2004 & 6.40 & 26.48 \\
2005 & 17.11 & 167.34 \\
2006 & 6.60 & -61.43 \\
2007 & 6.59 & -0.15 \\
2008 & 11.06 & 67.83 \\
2009 & 2.78 & -74.86 \\
2010 & 6.96 & 150.36 \\
2011 & 3.79 & -45.55 \\
2012 & 4.30 & 13.46 \\
2013 & 8.38 & 94.88 \\
2014 & 8.36 & -0.24 \\
2015 & 3.35 & -59.93 \\
2016 & 3.02 & -9.85 \\
2017 & 3.61 & 19.54 \\
\hline & & 44.67 \\
\hline Rata-rata & &
\end{tabular}

Sumber: Kementerian Perdagangan, 2018 (Diolah)

\section{Pengaruh Kurs, Harga, Produksi, Dan Inflasi Terhadap Ekspor Jahe}

\section{Uji asumsi Klasik}

Uji asumsi klasik mencakup uji multikolinearitas, uji autokorelasi, uji heterokedastisitas dan uji linearitas.

\section{Uji Multikolinieritas}

Multikolinearitas berarti adanya hubungan linear (sempurna atau tidak sempurna) diantara beberapa variabel maupun semua variabel bebas dalam model regresi. Multikolinearitas dapat dideteksi dengan cara melihat nilai $R^{2}$ yang tinggi, sebagian besar variabel bebasnya tidak signifikan, dan jika $R j^{2}$ lebih besar dari $R^{2}$ atau dengan melihat nilai variance inflation factors dengan ketentuan jika VIF kecil dari 10 maka penelitian bebas dari gejala multikolinearitas. Pengujian variance inflation factors (VIF) pada setiap variabel bebas. Hasil uji asumsi klasik pada uji multikolinearitas dapat dilihat pada Tabel 6.

Tabel 6. Uji Multikolinearitas

\begin{tabular}{cccc}
\hline Variable & $\begin{array}{c}\text { Coefficient } \\
\text { Variance }\end{array}$ & $\begin{array}{c}\text { Uncentered } \\
\text { VIF }\end{array}$ & $\begin{array}{c}\text { Centered } \\
\text { VIF }\end{array}$ \\
\hline C & 54384182 & 9.249095 & NA \\
KURS & 1.202218 & 15.42240 & 2.827036 \\
HARGA & 42369975 & 5.858248 & 1.585903 \\
PRODUKSI & 0.003039 & 11.54983 & 2.398538 \\
INFLASI & 43924.35 & 2.089633 & 1.352717 \\
\hline
\end{tabular}

Sumber: Data diolah (2018) 
Nilai VIF variabel kurs sebesar $2.827036<10$ maka variabel kurs bebas dari gejala multikolinearitas, variabel harga diperoleh nilai VIF sebesar $1.585903<10$ maka variabel harga bebas dari gejala multikolineraitas, variabel produksi diperoleh nilai VIF sebesar $2.398538<10$ maka varibel produksi bebas dari gejala multikolinearitas, dan variabel inflasi diperoleh nilai VIF sebesar $1.352717<10$ maka variabel inflasi bebas dari gejala multikolinearitas. Berdasarkan nilai VIF yang dijelaskan diatas dinyatakan semua variabel bebas dari multikolinearitas.

\section{Uji Autokorelasi}

Autokorelasi adalah korelasi antara anggota observasi yang berurutan menurut waktu, autokorelasi sering muncul pada data time series, dampak dari autokorelasi adalah tidak mempunyai varians minimum atau tidak lagi efisien, uji t dan uji f tidak sah. cara mendeteksi apakah suatu model regresi mengalami autokorelasi yaitu dengan memetakan $e_{t}$ terhadap waktu, jika grafik yang muncul memiliki pola atau memperlihatkan trend linear, kubik atau parabolik maka model regresi tersebut diduga mengandung autokorelasi. Hasil uji asumsi klasik pada uji autokorelasi dapat dilihat pada Tabel 7.

Tabel 7. Uji Autokorelasi

\begin{tabular}{lrll}
\hline Breusch-Godfrey Serial Correlation LM Test: & & \\
\hline F-statistic & 1.031026 & Prob. F(2,21) & 0.3740 \\
Obs*R-squared & 2.503570 & Prob. Chi-Square(2) & 0.2860 \\
\hline
\end{tabular}

Sumber : Data diolah (2018)

Nilai probabilita Chi-square lebih besar dari $\propto 5 \%(0,05)$ atau $0.2860>0.05$ dan tidak mengalami signifikan dalam model peengujian Breusch-Godfrey Serial Correlation LM Test, sehingga berarti bahwa Kurs, Harga, Produksi, dan Inflasi terhadap Ekspor Jahe bebas dari autokorelasi.

\section{Uji Heterokedastisitas}

Heterokedastisitas adalah penyebaran varians yang sama, ini berarti bahwa setiap variabel independen yang berhubunan denan variabel dependen mempunyai varians yang sama. sebaliknya, jika varians bersyarat variabel independen tidak sama pada berbagai nilai variabel dependen. cara mendeteksi apakah suatu model regresi mengalami heterokedastisitas, yaitu pertama melakukan metode grafik, dengan cara melihat grafik yang dihasilkan jika mempelihatkan trend linear, kubik maupun parabolik maka model regresi tersebut mengandung heterokedastisitas. Kedua, dengan cara melakukan pengujian Park. Uji heterokedastisitas digunakan untuk melihat ada atau tidaknya penyimpangan dari asumsi klasik. Jika terjadi heterokedastisitas maka penaksir OLS tetap tak bias dan konsisten, tetapi penaksir tadi tidak lagi efisien baik dalam sampel kecil maupun besar. Hasil uji asumsi klasik pada uji heterokedastisitas dapat dilihat pada Tabel 8.

Tabel 8. Uji Heterokedastisitas

\begin{tabular}{llll}
\hline F-statistic & 1.068661 & Prob. F(4,23) & 0.3946 \\
Obs*R-squared & 4.388325 & Prob. Chi-Square(4) & 0.3560 \\
Scaled explained SS & 5.469768 & Prob. Chi-Square(4) & 0.2424 \\
\hline
\end{tabular}

Sumber : Data diolah (2018).

Probabilita Chi-square lebih besar dari nilai probabilita $\propto 5 \%(0.05)$ atau $0.2424>$ 0.05 dan tidak mengalami signifikan dalam model pengujian Glesjer mengartikan bahwa Kurs, Harga, Produksi, dan Inflasi terhadap Ekspor Jahe menunjukkan bebas dari Heterokedastisitas.

\section{Uji Normalitas}

Uji normalitas dilakukan melalui test normality pada residual test histogram untuk mendeteksi apakah residualnya normal atau tidak dengan membandingkan nilai Jarque Berra 
(JB) dengan Chi Square $\left(X^{2}\right)$ tabel. Jika probabilitasnya lebih besar dari $\propto 5 \%$ maka uji normalitas diterima dan sebaliknya. Selain itu jika nilai JB $>$ Chi Square $\left(X^{2}\right)$ tabel maka residualnya berdistribusi tidak normal dan sebaliknya (Gunawan,2016). Hasil uji asumsi klasik pada uji normalitas dapat dilihat pada gambar 1.

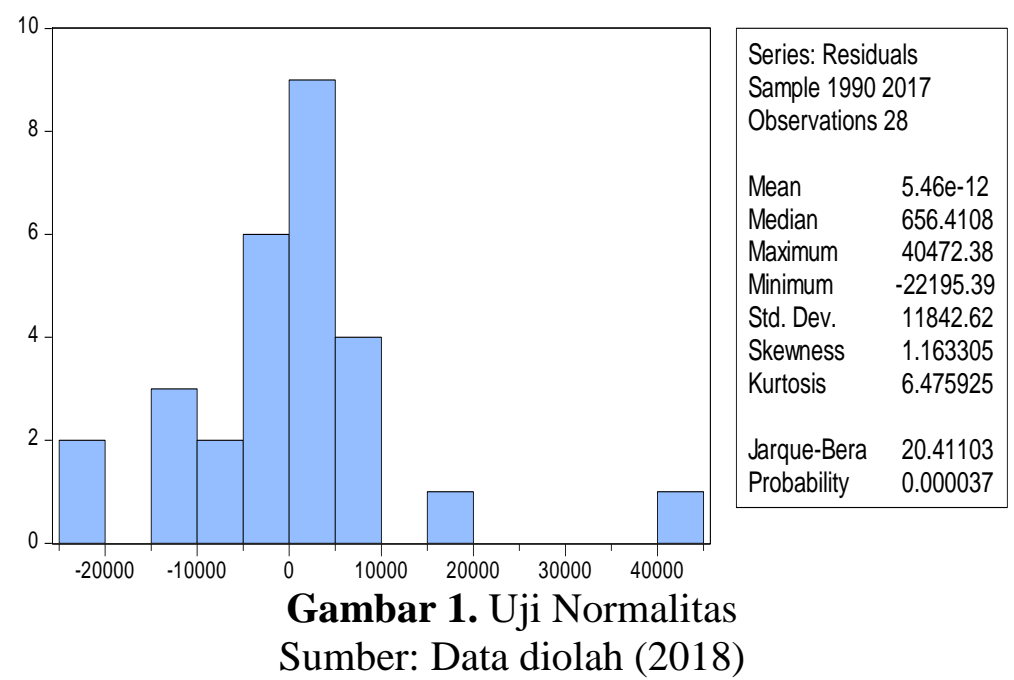

Nilai probabilita J-B lebih kecil dari nilai probabilita $\propto 5 \%(0.05)$ dalam pendekatan Jarque-Bera maka hipotesis yang menyatakan bahwa variabel pengganggu adalah berdistibusi normal ditolak.

\section{Uji Linearitas}

Salah satu kriteria BLUE (Best Linear Unbiased Estimator) adalah linear, artinya model regresi linear berganda tersebut memiliki nilai yang linear. Pengujian dapat menggunakan Ramsey Reset Test. jika nilai probabilita $\mathrm{F}$ hitung $\propto 5 \%$ maka model memenuhi asumsi linearitas dan sebaliknya (Nugraha,2017). Hasil uji asumsi klasik pada uji linearitas dapat dilihat pada Tabel 9.

Tabel 9. Uji Linearitas

\begin{tabular}{lccc}
\hline & Value & Df & Probability \\
\hline t-statistic & 0.664062 & 22 & 0.5136 \\
F-statistic & 0.440978 & $(1,22)$ & 0.5136 \\
Likelihood ratio & 0.555693 & 1 & 0.4560 \\
\hline
\end{tabular}

Sumber : Data diolah (2018)

Nilai probabilita F-statistik dan t-statistik sebesar $0.5136>0.05(\propto 5 \%)$. Hal ini berarti bahwa model regresi bebas dari linearitas.

\section{Estimasi model}

Estimasi model pengaruh kurs, harga, produksi dan inflasi terhadap ekspor jahe Indonesia diberikan pada Tabel 10.

Tabel 10. Estimasi Model Regresi

\begin{tabular}{cccc}
\hline Variable & Coefficient & t-Statistic & Prob. \\
\hline C & 36998.23 & 5.017006 & 0 \\
KURS & -4.407399 & -4.019674 & 0.0005 \\
HRG & -6830.282 & -1.049324 & 0.3049 \\
PROD & 0.207957 & 3.772373 & 0.001 \\
INF & 261.4529 & 1.2475 & 0.2248 \\
\hline R-squared & 0.577989 & & \\
F-statistic & 7.875229 & & \\
Prob(F-statistic) & 0.000376 & & \\
\hline
\end{tabular}

Sumber: Data diolah (2018) 


\section{Pengujian hipotesis}

\section{Uji F-Statistik}

Nilai F-hitung > F-tabel $(7.875229>2.80)$ dengan probabilita sebesar $0.000376<$ 0.05 (taraf signifikansi) artinya bahwa Ho ditolak Ha diterima pada tingkat keyakinan 95 persen sehingga dapat ditarik kesimpulan variabel bebas (kurs, harga, produksi, dan inflasi) secara bersama-sama berpengaruh signifikan terhadap ekspor jahe Indonesia.

\section{Koefisien Ddeteminasi $\left(R^{2}\right)$}

Nilai R-Square sebesar 0.577989 atau 57.79 persen sehingga dapat dinyatakan bahwa variabel bebas memiliki korelasi keeratan kuat terhadap ekspor jahe. Hal ini menjelaskan bahwa kurs, harga, produksi, dan inflasi berpengaruh sebesar 57.79 persen terhadap ekspor jahe sedangkan sisanya 42.21 persen dipengaruhi oleh variabel lain yang tidak dimasukkan dalam penelitian ini.

\section{Uji t-Statistik}

Variabel KURS diperoleh nilai probabilita sebesar $0.0005<0.05$ (taraf signifikansi) dan $t$ hitung $>\mathrm{t}$ tabel yaitu $4.019674>1.71387$. Maka Ho ditolak Ha diterima artinya secara parsial kurs berpengaruh negatif signifikan terhadap ekspor jahe (Y).

Variabel HARGA diperoleh nilai probabilita sebesar $0.3049>0.05$ (taraf signifikansi). Maka Ho diterima Ha ditolak artinya secara parsial inflasi tidak berpengaruh terhadap ekspor jahe (Y).

Variabel PRODUKSI diperoleh nilai probabilita sebesar $0.0010<0.05$ (taraf signifikansi) dan $t$ hitung $>\mathrm{t}$ tabel yaitu $3.772373>1.71387$. Maka Ho ditolak Ha diterima artinya secara parsial produksi berpengaruh positif signifikan terhadap ekspor jahe (Y).

Variabel INF (inflasi) diperoleh nilai probabilita sebesar $0.2248>0.05$ (taraf signifikansi) dan $\mathrm{t}$ hitung $<\mathrm{t}$ tabel yaitu $1.247500<1.71387$. Maka Ho diterima Ha ditolak artinya secara parsial inflasi tidak berpengaruh terhadap ekspor jahe (Y).

\section{Implikasi Model}

Variabel kurs rupiah terhadap US\$ (KURS) mempunyai nilai koefisien sebesar 4.407399 mengartikan bahwa kurs berpengaruh negatif terhadap ekspor jahe. Jika kurs mengalami peningkatan sebesar 1 rupiah maka ekspor jahe mengalami penurunan sebesar 4.407399 ton dengan asumsi variabel lain konstan. Temuan penelitian ini sejalan dengan temuan Yuliana \& Wirawan (2015) dan Aditama dkk (2015).

Variabel Harga jahe dunia (HRG) mempunyai nilai koefisien sebesar 6830.282 mengartikan bahwa harga berpengaruh negatif terhadap ekspor jahe. Jika harga jahe mengalami peningkatan sebesar 1 US\$ maka ekspor jahe mengalami penurunan sebesar 6830.282 ton dengan asumsi variabel lain konstan.

Variabel Produksi jahe (PROD) mempunyai nilai koefisien sebesar 0.207957 mengartikan bahwa produksi berpengaruh positif terhadap ekspor jahe. Jika produksi mengalami peningkatan sebesar 1 ton maka ekspor jahe akan mengalami peningkatan sebesar 0.207957 ton dengan asumsi variabel lain konstan. Temuan penelitian ini sejalan dengan temuan Yuliana \& Wirawan (2015), namun berbeda dengan temuan Aditama dkk (2015)

Variabel inflasi (INF) mempunyai nilai koefisien sebesar 261.4529 mengartikan bahwa inflasi berpengaruh positif terhadap ekspor jahe. Jika inflasi mengalami peningkatan sebesar 1 persen maka ekspor jahe mengalami peningkatan sebesar 261.4529 ton dengan asumsi variabel lain konstan.

\section{Kesimpulan}

\section{Kesimpulan dan Saran}

Selama periode 1990-2017 rata-rata perkembangan kurs sebesar 9.43 persen, rata-rata perkembangan harga jahe dunia sebesar -0.64 persen, rata-rata perkembangan produksi jahe sebesar 10.17 persen, dan rata-rata perkembangan inflasi sebesar 44.67 persen. Dari hasil 
regresi variabel kurs berpengaruh negatif signifikan terhadap ekspor jahe Indonesia. Variabel produksi berpengaruh positif signifikan terhadap ekspor jahe Indonesia. Sedangkan variabel harga dan inflasi tidak berpengaruh terhadap ekspor jahe Indonesia.

\section{Saran}

Mewujudkan potensi yang dimiliki jahe dengan cara meningkatan ekspor jahe pengusaha jahe harus meningkatkan produksinya, pemerintah diharapkan menjaga kestabilan perekonomian Indonesia sehingga harga tetap stabil dipasar dan diharapkan memberikan kemudahan dalam perizinan, dan perluasan pasar ekspor. Pemerintah dapat memperluas pasar dengan menjadikan negara tujuan utama ekspor jahe ke seluruh negara bagian dunia, dengan cara memberi bantuan pelatihan dan pembinaan mengenai budidaya jahe dan teknologi pengolahan berbagai bentuk jahe, dan membantu penangkaran benih jahe yang dapat membantu petani untuk mendapatkan benih berkualitas. Bukan hanya diberi bantuan bibit serta pupuk murah dan pelatihan serta pembinaan pemerintah juga dapat memberikan tenaga penyuluh ahli hingga proses panen maka diharapkan kualitas dan kuantitas jahe di Indonesia lebih baik dan mampu menguatkan daya saing di pangsa pasar jahe dunia.

\section{Daftar Pustaka}

Aditama, L.G., Yulianto, E. \& Wilopo. (2015). Pengaruh Produksi Dan Nilai Tukar Terhadap Volume Ekspor (Studi pada Volume Ekspor Jahe Indonesia ke Jepang Periode 19942013). Jurnal Administrasi Bisnis, 25(1), 1 - 9

Badan Pusat Statistik. (2006). Statistik tanaman biofarmaka Indonesia. https://www.bps.go.id/publication/2006/05/15/72c5ee51af850f9c6528ae2c/statistiktanaman-biofarmaka--obat-obatan--dan-hias-2005.htm

Badan Pusat Statistik. (2017). Analisa Komoditi Ekspor, 2010-2017, Sektor Pertanian, Industri, dan Pertambangan. Biro Pusat Statistik

Badan Pusat Statistik. (2018). Kurs rupiah terhadap dollar Amerika Serikat dalam angka. BPS Jambi.

Badan Pusat Statistik. (2018). Produksi jahe Indonesia dalam angka. BPS Jambi.

Direktorat Jenderal Perkebunan (2018). Perkembangan tanaman obat Indonesia 2017. ditjenbun.pertanian.go.id

Gunawan, G. (2016). Analisis ekspor komoditi unggulan perkebunan Provinsi Jambi Periode 2000-2014. Perdagangan Industri dan Moneter, 4(2).

Kementerian Perdagangan. (2018). Inflasi dalam angka. www.kemendag.go.id

Kementerian Perdagangan. (2018). Volume ekspor dalam angka. www.kemendag.go.id

Mindamora, M. S. (2000). Analisis faktor-faktor yang mempengaruhi produksi dan ekspor jahe Indonesia [Skripsi]. Fakultas Pertanian Institut Pertanian Bogor.

Nugraha, W. (2017). Pengaruh PDB Dunia, Indeks Harga Ekspor, dan Kurs terhadap Nilai Ekspor Nonmigas Indonesia [Skripsi]. Fakultas Ekonomi dan Bisnis Universitas Jambi.

Pribadi, E. (2015). Pasokan dan Permintaan Tanaman Obat Indonesia Serta Arah Penelitian dan Pengembangannya. Perspektif, 8(1), 52-64.

Salim, Z., \& Munadi, E. (2017). Info Komoditi Tanaman Obat. Badan Pengkajian dan Pengembangan Perdagangan Kementerian Perdagangan Republik Indonesia.

Yuliana, S. \& Wirawan, I.G.P.N (2015).Pengaruh Luas Lahan, Jumlah Produksi Dan Kurs Dollar Amerika Serikat Terhadap Volume Ekspor Jahe Indonesia Tahun 1993-2012. E-Jurnal EP Unud, 4(5), 367 - 374 